\title{
GEGEVENS OMTRENT HET GESCHENK TER GELEGENHEID VAN HET 25-JARIG HUWELIJKS- FEEST VAN HET KONINKLIJK ECHTPAAR DOOR DE BEVOLKING VAN SURINAME AANGEBODEN \\ DOOR \\ FRED. OUDSCHANS DENTZ
}

In de laatste vergadering van het huldigingscomité op 17 April $1926^{1}$ ) deelde de voorzitter, mr. S. D. de Vries, mede, dat hij met den secretaris, R. D. Simons en den penningmeester, mr. A. van Traa, eenige maanden tevoren het initiatief had genomen om gelden in te zamelen om het Koninklijk echtpaar bij diens zilveren huwelijksfeest wederom een geschenk uit Suriname te kunnen aanbieden.

Aan bijdragen uit Paramaribo ontving het comité $f 2.451,80$ en uit de districten $f 1.198,43$, t.w. uit Beneden-Commewijne: $f 336,75$, uit Boven-Suriname en Boven-Para: $f 237,93$, uit Boven-Commewijne en Cottica: $f$ 182, uit Saramacca: $f 136,15$, uit Marowijne : $f$ 91, uit Nickerie: $f 90,60$, uit Coronie: $f 89,25$ en uit Beneden-Suriname en Beneden-Para: $f 34,75$.

Voor deze som van $f 3650,23$ werden aangekocht:

A. Ten behoeve van H.M. de Koningin:

1. Een waaierketting samengesteld uit pepieten . . . . . . . . . . . $f$ 483.-

2. Doos ingelegd met gekroonde $\mathrm{W}$ en jaartallen versierd met gouden scharnieren, goud slot en staande op gouden pootjes. . . . . . . . . . 337.50

3. Zes gouden menuhouders, voorstellend het oude Surinaamsche wapen . . - 1200.-

4. Doos voor deze menuhouders . . . . - 46.- $f 2066.50$

1) Zie bladz. 13. 
B. Ten behoeve van Z.K.H. den Prins der Nederlanden:

1. Stuk kwarts met goudaderen voor presse-papier . . . . . . . . . . . . . $f$ 70.-

2. Goud voor het vervaardigen van het voetstuk der presse-papier . . . . . - 1200.-

3. Doos voor de presse-papier . . . . . - 22.- $f$ 1292.-

C. Administratiekosten, verzendings- en verzekeringskosten enz. . . . . . f 53.05

D. Voordeelig saldo . . . . . . . . . 238.68

$$
\text { Tezamen ... . } \overline{f 3650.23}
$$

Het saldo werd, overeenkomstig het verlangen der Koningin, afgestaan ten behoeve der slachtoffers van den watersnood in Nederland. Het werd op 14 April 1926 afgedragen aan den penningmeester van de groep Suriname van het Algemeen Nederlandsch Verbond, A. Ph. Samson, die penningmeester was van het plaatselijk comité tot inzameling van gelden ten behoeve van de slachtoffers van den watersnood.

Wat de gouden waaierketting van de Koningin betreft, kan worden medegedeeld, dat deze 1,52 lang was een gewicht aan zuiver goud van 161 gram had en in een slangenhouten doos was verpakt, waarop als motief kolibri's voorkomen, honing uit de bloemen van een stefanoot zuigende. Elke parel van de gekroonde $\mathrm{W}$ is ingelegd. Op een lint van Oranjehout zijn de data aangebracht 1901-2 Februari-1926. De voetjes, slot en scharnieren zijn van Surinaamsch goud (80 gram).

De pressepapier voor den Prins heeft een grondvlak van massief Surinaamsch goud (676 $\frac{1}{2}$ gram), waarop een stuk kwarts van 50 gram bevestigd is, zichtbaar doorregen met goud en afkomstig van het placer der Cie des mines d'or.

De menuhouders wegen ieder een ons en zijn van zuiver goud.

Het goudsmidswerk van de ketting en menuhouders was van den goudsmid M. A. Abrahams, dat van de presse-papier van S. J. Robles, de doozen waren door den schrijnwerker De Meer vervaardigd en het bekleeden der doozen was geschied door de eerwaarde sœurs. 